\title{
RESIDENTIAL FACTORS OF PNEUMONIA: A LITERATURE REVIEW
}

\author{
Yustini Ardillah ${ }^{1}$, Indah Purnama Sari ${ }^{2}$, Iwan Stia Budi ${ }^{3}$ \\ ${ }^{1}$ Program Studi Kesehatan Lingkungan Universitas Sriwijaya, Palembang \\ ${ }^{2}$ Program Studi Kesehatan Masyarakat Universitas Sriwijaya, Indralaya Ogan Ilir \\ ${ }^{3}$ Program Studi Kesehatan Masyarakat Universitas Sriwijaya, Indralaya Ogan Ilir
}

\begin{abstract}
Pneumonia remains a problem among children around the world and becomes a deadly disease among children under five years of age. It contributed 16\% of 5,6 millions of death of children.UNICEF stated that 24000 children were dead because of pneumonia each day. This study aim was to explain the residential factors of Pneumonia. This was a literature review from some journals and books. Inadequate healthy house takes part in spreading Pneumonia among children. Improving the residential environment could be prioritized to prevent Pneumonia from spreading bigger.
\end{abstract}

Keywords: Children, pneumonia, residential

\section{FAKTOR-FAKTOR LINGKUNGAN RUMAH DARI KEJADIAN PNEUMONIA: LITERATURE REVIEW}

\begin{abstract}
ABSTRAK
Pneumonia tetap menjadi masalah di antara anak-anak di seluruh dunia dan menjadi penyakit mematikan di antara anak-anak di bawah usia lima tahun. Ini menyumbang 16\% dari 5,6 juta kematian anak-anak. UNICEF menyatakan bahwa 24000 anak meninggal karena pneumonia setiap hari. Tujuan penelitian ini adalah untuk menjelaskan faktorfaktor perumahan Pneumonia. Ini adalah tinjauan literatur dari beberapa jurnal dan buku. Rumah sehat yang tidak memadai ikut serta dalam penyebaran pneumonia pada anak-anak. Memperbaiki lingkungan perumahan dapat diprioritaskan untuk mencegah penyebaran Pneumonia lebih besar.
\end{abstract}

Kata Kunci: Anak-anak, pneumonia, perumahan

\footnotetext{
1 Correspondece Address: Yustini Ardillah, Street Palembang Prabumulih KM 32, Indralaya District Ogan Ilir, South Sumatera Email: yustiniardillah@gmail.com
} 


\section{INTRODUCTION}

Pneumonia remains the main cause of death in children aged under five years old worldwide, it was recorded in 1.6 million deaths of children under 5 years there are $18 \%$ was due to pneumonia. Death due to pneumonia in children under five is closely related to malnutrition, poverty, the environment, and inadequate access to health services. Pneumonia is commonly found in countries with lower middle income, one of them in Asia and Africa. ${ }^{1}$ In developing countries like Indonesia, pneumonia was the second leading cause after diarrhea in under-five deaths. An increase in the incidence of pneumonia was reported in 2007 by $2.1 \%$ to $2.7 \%$ in 2013 . According to the Indonesian Health Profile, the number of cases of pneumonia in children under five years of age in Indonesia in 2015 increased from $63.45 \%$ to $65.27 \%$ in $2016 .{ }^{1}$

Environmetal factors, especially the environment influence respiratory infection. A slum environment that is used as a place to live can facilitate the occurrence of respiratory health problems caused by limited housing eligibility. This is based on the environment inside and outside the home. ${ }^{2}$ Walker, Rudan ${ }^{3}$ said that the fundamental factors that caused the high morbidity and mortality of pneumonia for children under five in developing countries were extensive poverty, low health status, very little health financing and poor socio-ecological status. Poor socio-ecological status is characterized by the poor environment, slums and dense residential areas, indoor pollution due to the use of biomass (household fuel from wood and rice husks), and outdoor air pollution. Both the inadequate level of education of mothers and the existence of local customs and beliefs that were wrong. Houses or shanty residences can support the transmission of diseases and health problems, including respiratory infections, such as common cold, tuberculosis, influenza, measles, whooping cough. Therefore, the aim of this study is to explain residential Pneumonia factors.

\section{METHOD}

This was a literature review study. To elaborate on this topic we collected some data based on journals both national and international journal, meanwhile, we also collected theoretical.

\section{RESULT}

There are six variables discussed in this study. All variables are confirmed by previous study that had significant relationship with Pneumonia. Those variables are dweller density, indoor air pollution, house ventilation, house humidity, house lighting adequacy and house temperature. The six variables are residential factors.

\section{DISCUSSION}

Pneumonia is caused by the bacteria Pneumococcus,Staphylococcus,Streptococcus. ${ }^{3}$ Pneumonia can be caused by a variety of organisms, namely bacteria, viruses, and fungi. The most common cause of bacterial pneumonia in children is Streptococcus pneumoniae, Haemophilus influenzae type b (Hib) the second most common cause of bacterial pneumonia. Respiratory Syncytial Virus (RSV) is the most common cause of the pneumonia virus. In infants infected with HIV, Pneumocystis bacteria is one of the most common causes of pneumonia and is responsible for at least a quarter of all deaths due to pneumonia in infants infected with HIV 
Rudan, O'brien ${ }^{4}$ reported that the physical condition of the home environment that did not meet health needs increased the risk of trans-mission disease. This study found that the physical environment of the house (ie temperature, the intensity of natural lighting, type of wall, house floor, ventilation, humidity, and occupancy density) were significantly associated with pneumonia risk. The Government of Indonesia has established regulations regarding housing health requirements, namely Decree of the Minister of Health of the Republic of Indonesia No. 829/MENKES/SK/VII/1999 concerning Housing Health Requirements.

A house with a dense population can cause an unhealthy house due to lack of oxygen consumption as well if one family member is infected with an infectious disease, it can be easily transmitted to other family members. The floor area of the house must be adjusted to the number of occupants so as not to overload. Based on the Decree of the Minister of Health of the Republic of Indonesia No.1077/MENKES/PER/V/2011 concerning housing requirements, it is said that the house is densely populated if the ratio of the floor area to the number of occupants is less than 10 square meters for one person, while for the bedroom size a minimum area of 3 square meters for one person is required. ${ }^{5}$ Dwelling density in the home increases exposure and risk of transmission between family members, especially diseases with air transmission media. ${ }^{6}$ Based on ${ }^{6}$ it has been proven that occupancy density has a relationship with the incidence of pneumonia in infants.

Cigarette smoke pollution plays a risk factor. Mother children who smoke have a tendency to get ARI more often than children whose mothers do not smoke (16\% versus $11 \%)$. Cigarettes are very dangerous and poisonous, cigarette smoke contains thousands of toxic chemicals and carcinogens. The harmful ingredients in cigarettes not only harm active smokers, they also harm those around them called passive smokers. Side smoke generated from smokers has a higher concentration because it does not go through an adequate screening process. Thus passive smokers have a higher risk of suffering from health problems. $^{7}$ Passive smokers have a higher risk of developing lung cancer and heart disease, whereas fetuses, infants, and children are at greater risk for developing low birth weight (LBW), bronchitis, pneumonia, ear cavity infections and asthma. According to Fahimah, Kusumowardani ${ }^{5}$ children who live with family members who smoke have a 6.37 times higher risk of developing pneumonia compared to those who live with family members who don't smoke. Polycyclic Aromatic Hydrocarbon (PAHS) is harmful to human health from burning tobacco products that are usually in the form of tobacco smoke (Environmental Tobacco Smoke/ETS). Cigarette smoke contains toxic and carcinogenic substances and can cause airway irritation by sulfur dioxide, ammonia, and formaldehyde. ${ }^{8}$ Nearly 3 billion people around the world burn solid fuels indoors. These fuels include biomass and coal. Although solid fuel smoke indoors is likely to be a greater problem in developing countries, populations that burn wood in developed countries may also be at risk of this exposure. ${ }^{7,9}$ Although large populations are at risk throughout the world, the effects of exposure to solid fuel smoke indoors have not been sufficiently studied in Indonesia. The results of this study indicated that there was a significant effect of exposure to biomass fuel smoke on the risk of pneumonia. Children with high smoke exposure to biomass fuel have an 8.29 times higher risk of developing pneumonia compared to those who had low smoke exposure. The results of this study were also 
supported Sanbata, Asfaw, ${ }^{10}$ who reported that children who live at home with biomass fuel while cooking are at risk three times higher than Accute Respiratory Infection (ARI) or pneumonia compared to those who do not live at home with biomass fuel. Exposure to fuel smoke can come from wood, charcoal, husks and other biomass.

Fuels produce pollutants in high concentrations because the combustion process is not perfect. The use of cooking fuels such as charcoal, wood, petroleum, and coal creates a risk of air pollution and/or chemical contamination at home such as carbon dioxide (CO2), carbon monoxide (CO), sulfur dioxide (SO2), hydrogen sulfide (H2S), and dust particles with $10 \mu$ (PM10) in diameter, which increases the risk of ARI. The use of biomass fuel for cooking must be supported by quality kitchen construction such as kitchen pits and energy-efficient stoves to reduce smoke exposure. ${ }^{11}$ Another factor is the smoke of mosquito repellent that can enter the respiratory tract when breathing air, the poison in the mosquito coil will enter the blood in the alveoli of the lungs and then circulate throughout the body. If inhaled in a long term period will cause chest pain, difficulty breathing, asthma, and others. Toddlers are very substantial to be exposed to air pollution due to mosquito repellent and the impact on it is greater than that of adults. According to WHO mosquito repellent can trigger asthma, cancer because of its pollutant and carcinogenic properties, especially respiratory disorders. Previous research conducted by ${ }^{12}$ found that there was a significant relationship between the habit of using anti-mosquito coils and the incidence of pneumonia in children under five. OR value $=3.6$ which means that children under five who live with the habit of using antimosquito coils in the house have a risk 3.6 times more likely to get pneumonia compared to toddlers who don't live with the habit of using anti-mosquito coils in the house.

House ventilation has a function as a means of exchanging the air in the house so that fresh air circulates into the house and dirty air exits the house. Ventilation is useful to keep the airflow in the house to stay cool. To maintain the flow of air inside the house to keep it cool it is necessary to have a balance of $\mathrm{O} 2$, if $\mathrm{O} 2$ levels in the house are deficient then the $\mathrm{C} 02$ level will increase which can cause poisoning for the dwellers. ${ }^{8}$ Houses with inadequate ventilation will cause respiratory problems for dwellers. Transmission of respiratory diseases is caused by germs in the house can not be exchanged and then settles. The Previous study found that toddlers who live in homes with ventilated areas do not meet the risk of having pneumonia 3.85 times greater than toddlers who live in homes with ventilated areas that qualify. ${ }^{5,12-14}$

Humidity is one of the environmental factors that can affect the growth of the battery where the higher the moisture eat the faster the bacterial proliferation. According to the Decree of the Minister of Health of the Republic of IndonesiaNo.1077/MENKES/PER/V/2011 humi dity is considered good if it meets $40 \%-60 \%$ and poor if $<40 \%$ and $>60 \%$. High house humidity can affect a person's immune system and can increase their susceptibility to diseases, especially infectious diseases. Humidity can also be affected by several things such as the home environment that does not meet the requirements or the weather, for example in the rainy season, the humidity level will increase but if the condition of the house is good such as there is sunlight can enter, there is no standing water and adequate ventilation then the humidity can be maintained inside the house. Humidity is inversely related to air temperature when the air temperature is low, the humidity will increase. ${ }^{14,15}$ The previous study found that 
toddlers who live in homes with lighting that does not meet the requirements ( $<60$ lux) have a risk of pneumonia 4.8 times greater than toddlers who live with lighting that meet the requirements.

According to the Decree of the Minister of Health of the Republic of Indonesia No. 1077/MENKES/PER/V/2011 the minimum standard for natural lighting that meets health requirements is 60 lux. Natural lighting is very important in order to reduce humidity and can kill pathogenic bacteria. Houses that can be said to be healthy one of which requires adequate lighting (sunlight), no less and no more. Lack of light entering the house, especially natural sunlight, can cause discomfort and can also make a good medium for the proliferation of a disease, one of which is pneumonia. Zairinayati, Udiyono $^{16}$ stated that toddlers who live in homes with lighting that does not meet the requirements $(<60$ lux $)$ have a risk of pneumonia 4.8 times greater than toddlers who live with lighting that meet the requirements.

\section{REFRENCES}

1. WHO. Pneumonia Fact Sheets: World Health Organization; 2016 [cited 201820 Mei].Availablefrom:http://www.who.int/ mediacentre/factsheets/fs331/en/.

2. Mentese S, Mirici NA, Otkun MT, Bakar C, Palaz E, Tasdibi D, et al. Association between respiratory health and indoor air pollution exposure in Canakkale, Turkey. Building and Environment. 2015;93:7283.

3. Walker CLF, Rudan I, Liu L, Nair H, Theodoratou E, Bhutta ZA, et al. Global burden of childhood pneumonia and diarrhoea.TheLancet.2013;381(9875):140 5-16.

4. Rudan I, O’brien KL, Nair H, Liu L, Theodoratou E, Qazi S, et al. Epidemiology and etiology of childhood pneumonia in 2010: estimates of
One of the physiological requirements of the house according to the Decree of the Minister of Health of the Republic of Indonesia No. 1077/MENKES/PER/V/2011 is having an optimum temperature of $18^{\circ} \mathrm{C}-30^{\circ} \mathrm{C}$. Pneumonia is caused by several microorganisms (bacteria, viruses, fungi) whose growth is affected by room temperature. Where there is a minimum or maximum temperature to survive and grow in the environment. ${ }^{15}$ Streptococcus pneumonia itself has an optimum growing temperature of $37^{\circ} \mathrm{C}$, able to live at a minimum temperature of $10^{\circ} \mathrm{C}-15^{\circ} \mathrm{C}$ and a maximum temperature of $45^{\circ} \mathrm{C} .^{11}$

\section{CONCLUSION}

Residential factors take part in spreading Pneumonia. House temperature, humidity, lighting, ventilation and indoor air pollution are variables that could be intervened through fixing up the house condition.

incidence, severe morbidity, mortality, underlying risk factors and causative pathogens for 192 countries. Journal of global health. 2013;3(1).

5. Fahimah R, Kusumowardani E, Susanna D, Lingkungan K, Masyarakat F, Indonesia U. Kualitas Udara Rumah dengan Kejadian Pneumonia Anak Bawah Lima Tahun (di Puskesmas Cimahi Selatan dan Leuwi Gajah Kota Cimahi). Makara J Health. 2014;18(1):25-33.

6. Efni Y, Machmud R, Pertiwi D. Faktor risiko yang berhubungan dengan kejadian pneumonia pada balita di Kelurahan Air Tawar Barat Padang. Jurnal Kesehatan Andalas. 2016;5(2).

7. Jones AP. Indoor air quality and health. AtmosphericEnvironment.1999;33(28):45 35-64. 
8. Wang $\mathrm{T}$, Zhao Z, Yao $\mathrm{H}$, Wang $\mathrm{S}$, Norback D, Chen $J$, et al. Housing characteristics and indoor environment in relation to children's asthma, allergic diseases and pneumonia in Urumqi, China. Chinese Science Bulletin. 2013;58(34):4237-44.

9. Özbay B, Uzun Ks, Arslan H, Zehir Is. Functional and radiological impairment in women highly exposed to indoor biomass fuels. Respirology. 2001;6(3):255-8.

10. Sanbata H, Asfaw A, Kumie A. Association of biomass fuel use with acute respiratory infections among underfive children in a slum urban of Addis Ababa, Ethiopia. BMC public health. 2014;14(1):1122.

11. Lévesque B, Huppé V, Dubé $M$, Fachehoun RC. Impact of indoor air quality on respiratory health: results of a local survey on housing environment. Public Health. 2018;163:76-9.

12. Nuretza JA, Suhartono S, Winarni S. Hubungan antara Perilaku Keluarga dan Kondisi Lingkungan dalam Rumah Tangga dengan Kejadian Pneumonia pada
Anak Balita di Wilayah Kerja Puskesmas Halmahera Kota Semarang. Jurnal Kesehatan Masyarakat (e-Journal). 2017;5(5):696-705.

13. Nguyen TKP, Tran TH, Roberts CL, Fox GJ, Graham SM, Marais BJ. Risk factors for child pneumonia focus on the Western Pacific Region. Paediatric Respiratory Reviews. 2017;21:95-101.

14. Prajadiva G, Ardillah Y. Determinan Lingkungan Fisik Rumah Terhadap Pneumonia pada Balita di Pinggiran Sungai Musi. Jurnal Kesehatan. 2019(1):1-11.

15. Fisk WJ, Eliseeva EA, Mendell MJ. Association of residential dampness and mold with respiratory tract infections and bronchitis: a meta-analysis. Environmental Health. 2010;9(1):72.

16. Zairinayati Z, Udiyono A, Hanani Y. Analisis faktor lingkungan fisik rumah yang berhubungan dengan kejadian pneumonia pada balita di wilayah kerja Puskesmas Sosial Kecamatan Sukarame Palembang. Masker Medika. 2013;1(2):11-20. 